DOI: https://doi.org/10.20535/2707-2096.6.2021.241934

УДК 622.271

I.K. Babychev*, PhD student ORCID: 0000-0002-5771-1087

I.M. Yevtushenko, student O.O Frolov, Dr. sciences, prof., ORCID: 0000-0001-8053-2653

Igor Sikorsky Kyiv Polytechnic Institute, Kyiv, Ukraine

*Corresponding author: i.babichev@ukr.net Received 21.09.2021; Accepted 30.09.2021

\title{
SIMULATION OF JOINT FORMATION OF CAREER OVERBURDEN ROCK WITH PLACEMENT OF IRON ORE ENRICHMENT WASTE
}

Purpose. The purpose of the research presented in the article is to substantiate the possibility of dump formation during joint dumping of quarry overburden rocks and iron ore wastes during the development of the Horishne-Plavnivsky deposit of iron quartzites.

Task. Perform geomechanical modeling of the behavior of the quarry dump with the placement of funnels with enrichment wastes and establish the possibility of their joint storage in the dumps of the Horishno-Plavnivskoye deposit; to establish regularities of development of deformation processes in a dump in process of construction of each layer at dump of wastes of enrichment in funnels and to calculate a factor of a stock of stability of a dump after its formation.

Research methods. To achieve the goal of research used: the method of complex analysisto summarize previous research on the establishment and justification of the most rational method of dumping of enrichment waste; modeling methods - to establish the possibility and feasibility of joint dumping of enrichment wests and overburden rocks from the quarry.

Scientific novelty. For the conditions of the Horishne-Plavnivsky deposit of ferrous quartzites by the method of geomechanical modeling the expediency and possibility of placement of dehydrated enrichment wastes in funnels on dump of overburden rocks is substantiated.

Conclusions and practical significance of the article. For research results the predicted behavior of a dump during all term of its use is received. The obtained values of the maximum deformations are deviated in the process of its formation by each of layer and the investigated efficiency of deformation at formation of the following layer is established. The indicator of the coefficient of safety of the stability of the corresponding deviation after its formation and building, which means that it exceeds the minimum, in accordance with current regulations $(n=1,329>1,3)$, after it is formation with further use joint dumping of overburden rocks and enrichment wastes is possible and appropriate.

Keywords: quarry, waste, iron ore, deposit, geomechanical modeling, deformation, stock ratio.

\section{INTRODUCTION}

Actuality of theme. After enrichment of iron ores at the enrichment plant, iron ore concentrate and tailings (waste of wet magnetic separation) are obtained, which enter the tailings pond for storage [1-4].

Every year the problem of dumping and storage of enrichment waste is exacerbated, as new additional land areas need to be allocated for tailings, which, at best, should be withdrawn from public circulation and, at worst, not at all. In this regard, scientists are developing new methods and 
technologies for storage of waste products of beneficiation, aimed at maximizing the capacity of the project parameters of the designed tailings and reducing the area of storage of beneficiation products.

When opencast iron ore is mined, one of the methods of solving the problem of tailings storage is their placement together with empty rocks on the dumps. However, in the process of design and direct construction of such compatible dumps there are certain difficulties, which are associated, first of all, with different conditions of storage and storage of open pit quarries and beneficiation products. In particular, the physical and mechanical properties of overburden and tail rocks, their heterogeneity and variability over time differ significantly. It is also impossible to accurately predict the physical and mechanical parameters of the mixed rock mass and the behavior of the compatible dump due to the load of the upper tiers of rocks.

Despite the large number of scientific publications and studies on the joint dumping of enrichment waste and overburden rocks on the same dump, a single methodology that would comprehensively cover the issues of geomechanics, safety, ecology, technology and economics, would take into account social factors and the process of reclamation of dumps after their formation. Therefore, the problem of joint dumping of overburden and tailings in dumps under different mining-geological and hydrogeological conditions of their placement is given much attention, and the establishment of effective methods and parameters of dumping is an urgent task in Ukraine and elsewhere where ores are mined. Its successful solution will provide an opportunity to rationally use land resources, safely operate dumps with less environmental impact and improve the technical and economic performance of the mining company as a whole.

Analysis of recent research and publications. The study and analysis of scientific research has allowed to some extent to generalize the existing technologies for dumping of enrichment waste. Usually the tails from enrichment plant are represented by finely ground sand, which is stored in the tailings in a dry or wet way. The wet method involves the arrangement of dams along the perimeter of the dump, and the supply of waste to the tailings is carried out in the form of pulp or pasty consistency. A layer of water must be placed on top of the tails to prevent dust formation.

Dry dumping is performed under the condition of enrichment of iron ore by anhydrous technology or, if after enrichment of ore with the involvement of water, use drying units. In this case, the technology of dry storage of beneficiation waste involves the addition of binders or chemical reagents that reduce dusting from the dry enrichment waste dump [2].

Among the existing types of dumping of tailings waste in tailings, the most common are [4]: pulplike waste; hydrocyclone waste; pasty waste; dry waste. Large areas of land are required for the storage of pulp-like waste, as slopes of the washed surface are formed. In particular, it is proved that the storage areas in dry dumps are 3 times smaller than the areas of land that are involved in the storage of pulp-like waste [3]. In addition, the disadvantages of this method include the high operating costs for dumping of tailings and the risks of breaking the dam.

A feature of hydrocyclone waste dumping is the distribution of tailings by fractions in the tailings. The heavier coarse-grained fraction is located near the dam, and the fine-grained fraction is located in the central part of the tailings. Waste dumping with the help of hydrocyclones is characterized by a significant increase in the cost of building a pioneer dam, sawing tailings, the complexity of construction in rainy weather [5].

When dumping pasty waste, their unloading is carried out from a height of 10-25 $\mathrm{m}$ in funnels with a diameter of $0.3-1.2 \mathrm{~km}$. This method can be used with the addition of a cement component. It does not require the construction of a large pioneer dam, which significantly reduces capital costs, also eliminates problems associated with the stability of the dump, there is no filtration of water into the soil, pasty waste is much safer than usual [5]. However, such technology requires the use of dumps, which significantly complicates the process of formation of tailings, and does not solve the main problem - reducing the area of land involved. Storage of pasty waste enrichment is effective only when the content of the solid component does not exceed 62\% (Fig. 1).

For dumping of dry waste enrichment involve motor transport or conveyor transport. There are three main technological stages: unloading, planning and compaction of tails. This method is characterized by high energy consumption, high operating costs, dusting and dependence on meteorological conditions [5]. 


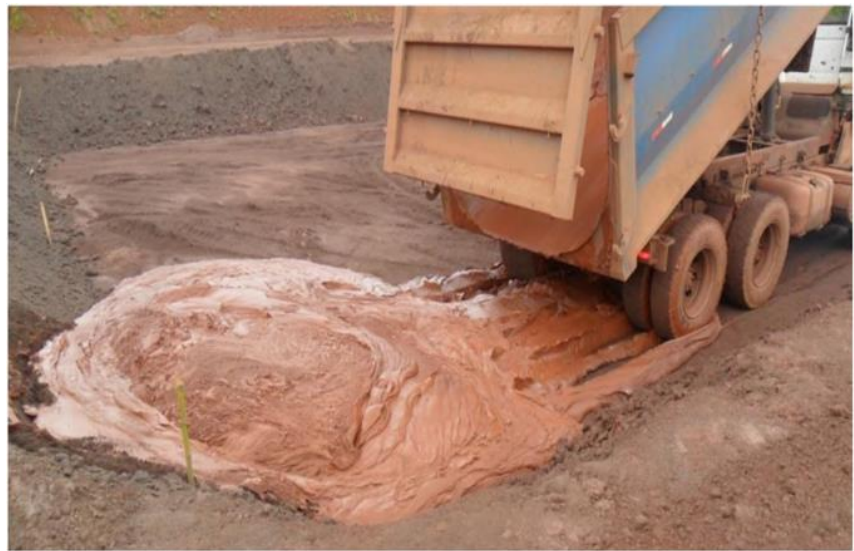

Figure 1 - Unloading of pasty enrichment waste at the landfill
The analysis of the above methods of dumping of enrichment waste shows that none of them solves the problem of reducing the area of land that is involved in tailings. This task can be achieved, in particular, by placing enrichment waste in the dumbs of quarry rocks. Research on the joint dumping of quarry overburden rocks and enrichment waste shows that the problem of reducing the area under the dumps is solved locally in specific conditions of the enterprise.

From the geomechanical point of view, the problem of stability of dumps with the joint placement of quarry overburden rocks and waste products has not been studied, as there was no need for this due to the separate storage of tailings. Only simulating of the behavior of overburden dumps in different mining-geological and technological conditions was performed, including soils, overburden rocks or their joint dump formation [6-12].

The aim of the study. Based on the above analysis of scientific research on the dumping of iron ore enrichment waste, the purpose of this article is formulated, which is to substantiate the possibility of dump formation in the joint dumping of quarry overburden rocks and iron ore enrichment waste in the development of Horishno-Plavnivinske iron ore deposit. The urgency of solving the problem of substantiating the parameters of a joint dump is due to the filling of the existing capacious volumes of sludge.

\section{THE MAIN PART}

Analysis of world experience shows that the joint dumping of enrichment waste with quarry overburden rocks is appropriate only in the dry state and can be performed in two ways [5]:

1) storage of dry waste enrichment with quarry opening rocks by bulldozer dump formation (Fig. 2);

2) storage of dry waste enrichment in funnels, which are formed on the main dump of overburden (Fig. 3).

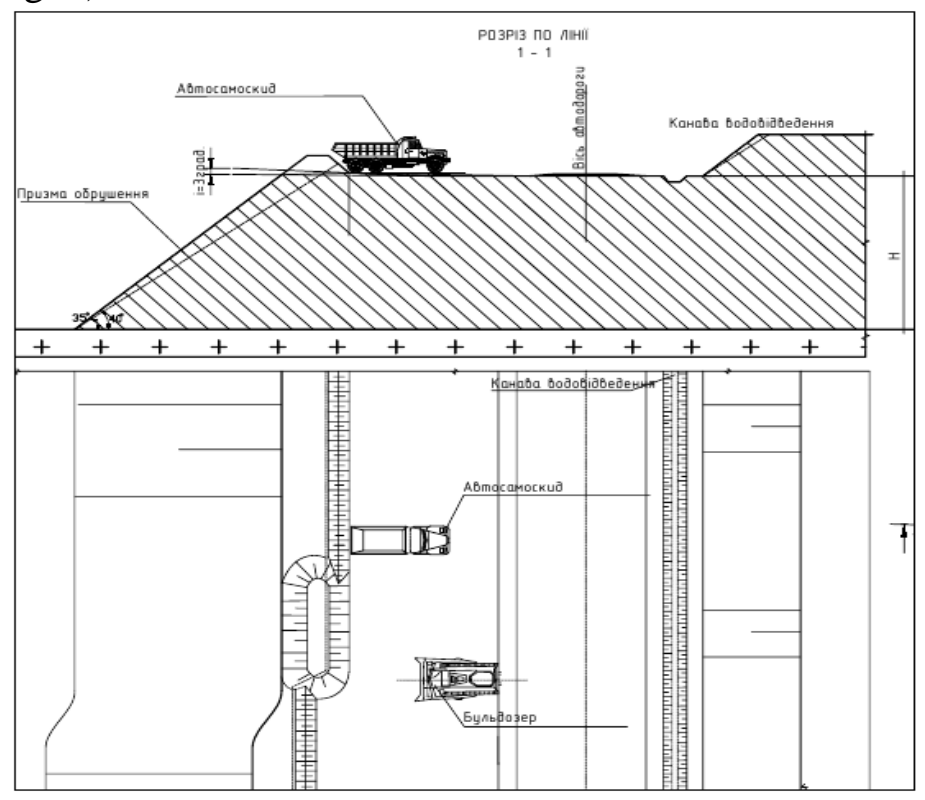

Figure 2 - Scheme of bulldozer dump formation with help of motor transport
To achieve this purpose, the option of storage of enrichment desiderated waste with a humidity in the range of $10-15 \%$ was chosen [13]. Despite the energy intensity of dry waste storage, this method is the easiest to implement and most solves the problem of shortage of tailings.

In the case of joint dumping of tailings and overburden by bulldozer dump formation, they will be segregated in any case when the bulldozer collides with the unloading site on the slope. According to the law of gravity, the overburden rocks, the particle size distribution of which is greater than the beneficiation waste, will slide down the tier, and smaller fractions will be placed closer to the top of the dump tier. 
According to the results of research in [14] it was found that due to the particle size distribution of sludge and the possible particle size distribution of overburden, it can be argued that the enrichment waste will be concentrated only in the upper tier and the sludge will not fall on the lower quarter of the dump tier.

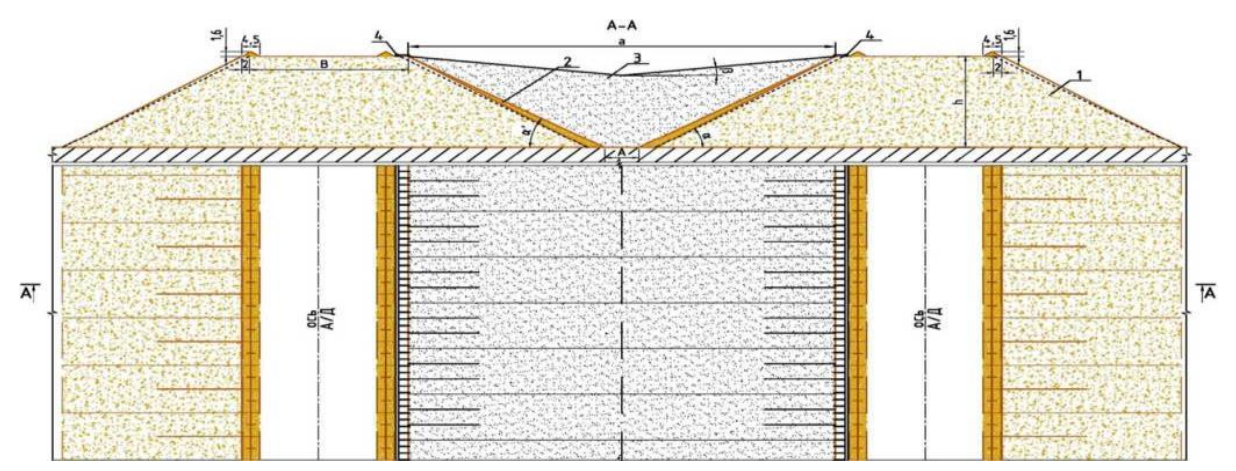

Figure 3 - Technological scheme of dumping in the funnel [5]

Storage of dry enrichment waste in funnels involves the primary dumping along the final contour of the dump (circle) of a strip of empty rocks opening a quarry width of $100.0 \mathrm{~m}$ (top). This lane will also serve as a transport berm, and later a buttress. In addition, water will drain through this strip along the entire slope of the tier of the dump. After backfilling, a strip of rock mass is formed inside to move the conveyor equipment. The width of the backfill strip inside the funnel is $40 \mathrm{~m}$ at the top to ensure the reversal of dump trucks. Such strips will serve as a kind of "reinforcing mesh" for the dump and together with it will form a single geomechanical structure.

Geomechanical modeling of quarry overbuden dump behavior with dehydrated enrichment waste is performed in Plaxis 3D software to establish the maximum allowable deformations and stresses that may occur during construction, and the of safety of the dump. The basis of mathematical modeling is the Coulomb-Mora model $[15,16]$, with the help of which, by the finite element method, it is possible to determine the deformations of both natural and artificially created rock massif and to establish its stability. In fig. 4 shows the design cross section in the middle of the dump of only overburden at the end of development (fig. $4, a$ ) and the same section of the dump, taking into account the placement of funnels with enrichment waste (fig. 4, $b$ ) [17].

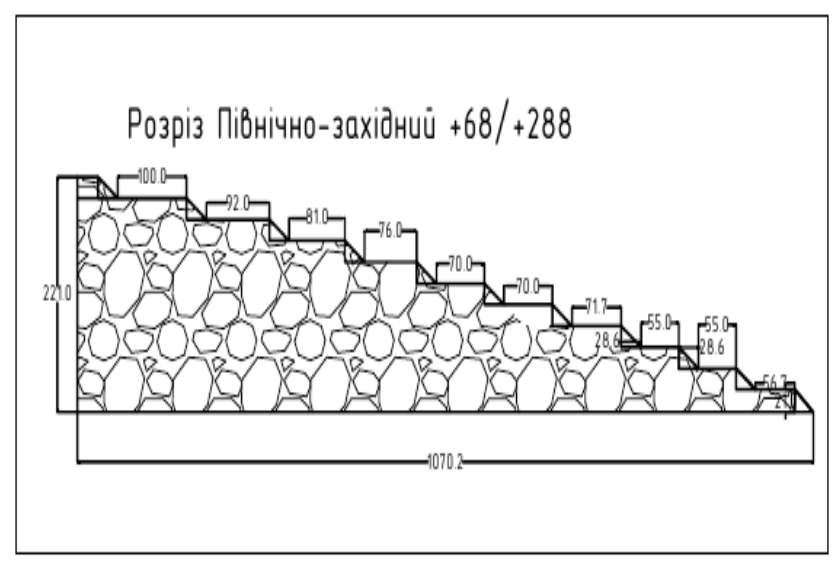

a)

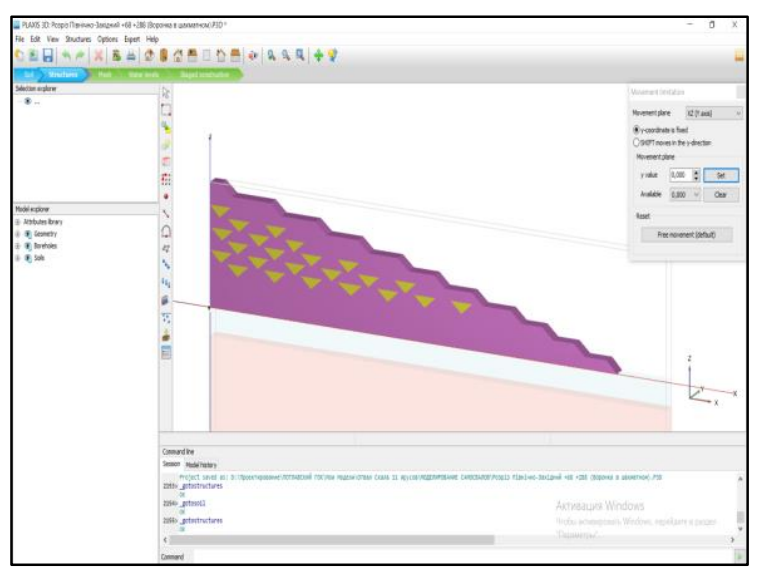

b)

Figure 4 - Design cross section of the slope of the dump: a - folded by a rock overburden; $b$ geomechanical model of the section with funnels in Plaxis $3 D$

The initial data for modeling are the design parameters of the dump of overburden and enrichment waste (Table 1) and their main weighted average physical and mechanical properties (Table 2) [17]. 
Table 1 - The main parameters of the design dump

\begin{tabular}{|c|l|c|c|}
\hline № & \multicolumn{1}{|c|}{ Parametr } & Dimensionality & Indicator \\
\hline 1 & \multicolumn{1}{|c|}{2} & 3 & 4 \\
\hline 1 & The number of existing layers of the dump & unit & 3 \\
\hline 2 & $\begin{array}{l}\text { Marks of horizons of layers of an existing } \\
\text { dump }\end{array}$ & $\mathrm{m}$ & $+70,0 ;+88,0 ;+108,0$ \\
\hline 3 & Number of design layers of the dump & unit & 11 \\
\hline 4 & Design mark of the dump & $\mathrm{M}$ & $+268,0$ \\
\hline 5 & The average height of the layers & $\mathrm{m}$ & 20,0 \\
\hline 6 & The angle of non-working slope of the dump & degree & $30-35$ \\
\hline 7 & Width of terraces & $\mathrm{m}$ & $50,0-80,0$ \\
\hline
\end{tabular}

Table 2 - The main weighted average physical and mechanical properties of rocks in the dump

\begin{tabular}{|c|l|c|c|c|c|}
\hline № & \multicolumn{1}{|c|}{ Parametr } & Dimensionality & Overburden & $\begin{array}{c}\text { Dehydrated } \\
\text { waste of } \\
\text { enrichment }\end{array}$ & $\begin{array}{c}\text { Overbuden } \\
\text { and wate }\end{array}$ \\
\hline 1 & \multicolumn{1}{|c|}{2} & 3 & 4 & 5 & 6 \\
\hline 1 & $\begin{array}{l}\text { Density in the } \\
\text { conditions of natural } \\
\text { occurrence }\end{array}$ & $\kappa \mathrm{H} / \mathrm{M}^{3}$ & 25,8 & 15,8 & 28,8 \\
\hline 2 & $\begin{array}{l}\text { Density in the } \\
\text { waterlogged state }\end{array}$ & $\mathrm{\kappa H} / \mathrm{M}^{3}$ & 28,8 & 17,4 & 28,8 \\
\hline 3 & Poisson's ratio & $\mathrm{\kappa H} / \mathrm{M}^{2}$ & 0,3 & 0,3 & 0,3 \\
\hline 4 & Adhesion & $\mathrm{\kappa H} / \mathrm{M}^{2}$ & 20,0 & 1,0 & 20,0 \\
\hline 5 & $\begin{array}{l}\text { The angle of internal } \\
\text { friction }\end{array}$ & град. & 30,64 & 26,0 & 30,64 \\
\hline
\end{tabular}

Geomechanical modeling was carried out in stages (layer by layer), starting from the construction of the 4th layer of the dump to the last layer, in order to determine the deformation processes and the stability of the dump. The simulation was performed from the 4th layer because 3 layer already exist [18]. In fig. 5 presents the results of modeling the 4th and last 11th layers of the dump. The last layer is modeled exclusively by overburden without funnel formation with dehydrated waste in order to reduce the sawing of the dump after its reclamation. The simulation results are presented in table 3 .

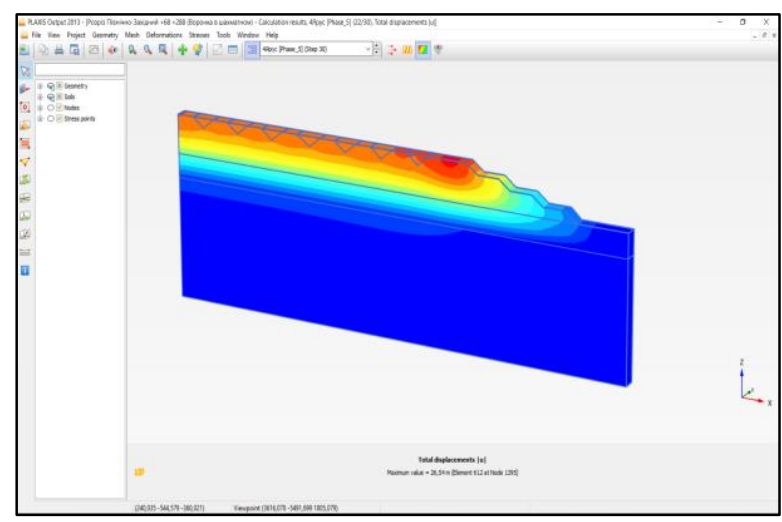

a)

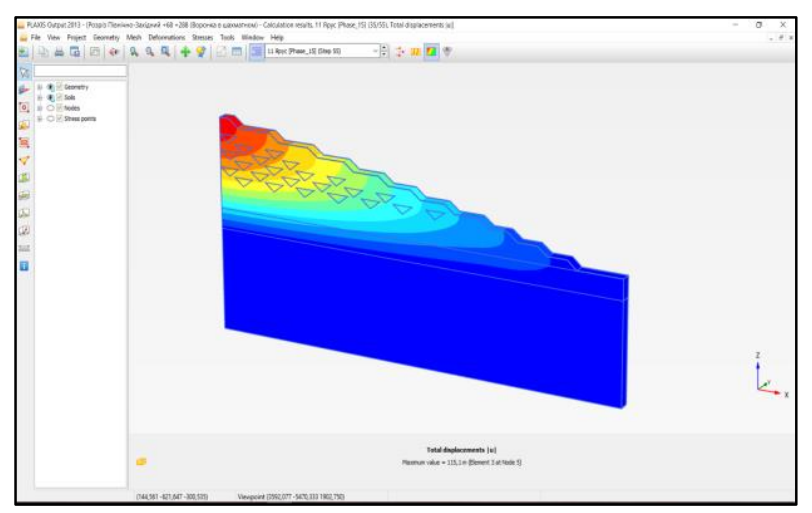

b)

Figure 5 - Geomechanical models in Plaxis 3D:

a - model of the 4th layer of the dump; b - model of a full dump 
Table 3 - Simulation results

\begin{tabular}{|c|c|c|c|c|c|c|}
\hline \multirow{2}{*}{ № } & № layer & $\Delta x$ & $\Delta y$ & $\Delta z$ & $\Delta U$ & $\begin{array}{c}\text { Maximum } \\
\text { deformations } \Delta \mathrm{U} / \text { their } \\
\text { increase with the } \\
\text { previous layer, } \mathrm{m}\end{array}$ \\
\cline { 2 - 6 } & 2 & 3 & 4 & 5 & 6 & 7 \\
\hline 1 & $1-3$ layers & 3,6 & 0,01 & 0,05 & 20,2 & 20,2 \\
\hline 1 & 4 layer & 3,1 & 0,03 & 0,5 & 10,1 & $26,5 / 6,3$ \\
\hline 2 & 5 layer & 2,9 & 0,02 & 0,3 & 11,4 & $35,8 / 9,3$ \\
\hline 3 & 6 layer & 3,1 & 0,02 & 0,3 & 12,8 & $46,3 / 10,5$ \\
\hline 4 & 7 layer & 3,3 & 0,01 & 0,2 & 14,1 & $59,0 / 12,7$ \\
\hline 5 & 8 layer & 3,6 & 0,02 & 0,3 & 15,1 & $72,8 / 13,8$ \\
\hline 6 & 9 layer & 3,7 & 0,01 & 0,3 & 16,4 & $86,1 / 13,3$ \\
\hline 7 & 10 layer & 3,7 & 0,01 & 0,3 & 18,3 & $103,4 / 17,3$ \\
\hline 8 & 11 layer & 1,8 & 0,01 & 0,1 & 11,7 & $115,1 / 11,7$ \\
\hline 9 & \multicolumn{7}{|c|}{ Stability coefficient } & & & & $\mathbf{1 , 3 2 9}$ \\
\hline
\end{tabular}

In fig. 6 presents the patterns of development of deformation processes in the dump as the construction of each layer in the joint dump of overburden and enrichment waste in funnels. From the diagram of the change of deformation along the layers there is a constant increase in deformation during the formation of each layer, but a clear pattern between the increase in deformation of neighboring layers is not observed.

From the table. 1 shows that the coefficient of stability of the dump of overburden under the condition of dumb of dehydrated waste from beneficiation in the funnels provides the value of the coefficient of stability more than 1.3 , which is the minimum allowable coefficient according to current regulations [19]. The calculation of the coefficient of safety margin is based on the condition of equilibrium of incoherent rocks on layer of the dump. Analytical calculation of the coefficient of stability is based on the theory of the limit equilibrium of the "bulk medium", which also includes the limit equilibria of the connected medium with friction, which includes the dump of overburden [20].

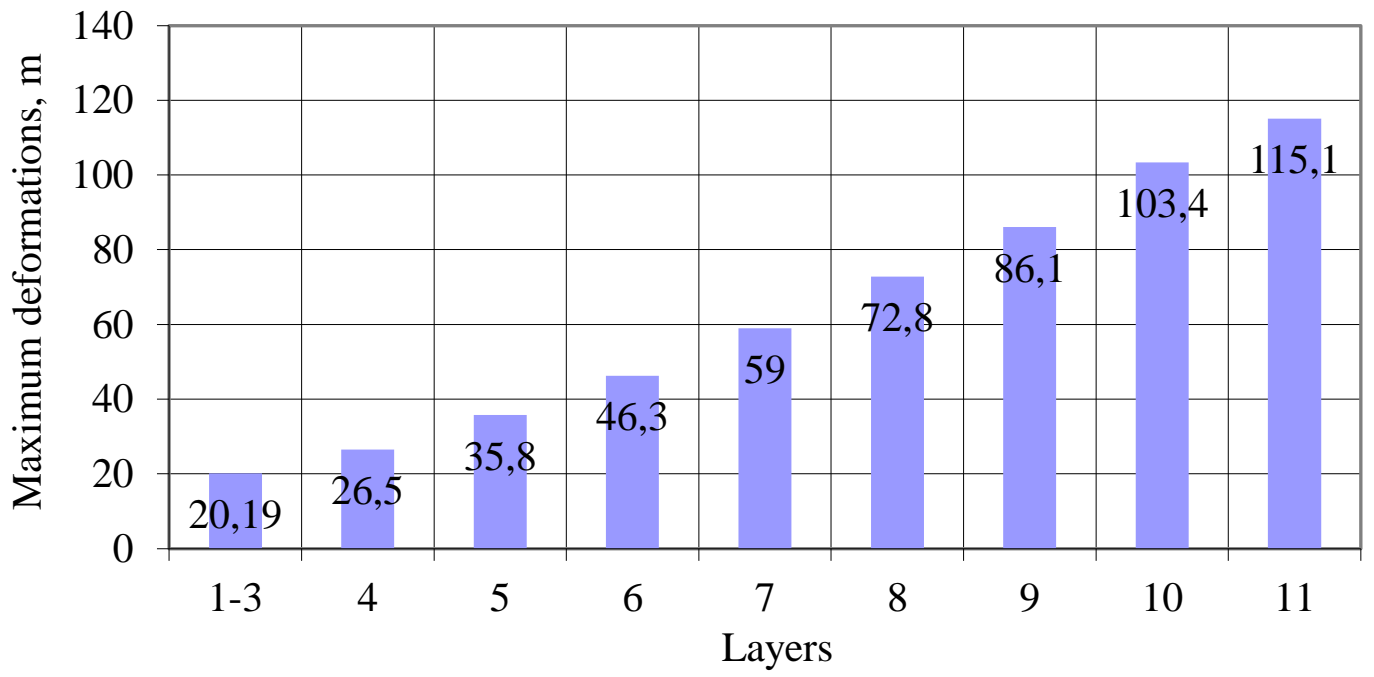

Figure 6 - Diagram of deformation of the dump in layers

Based on the above, the coefficient of stability of the slope of the layer of the dumb $n$ by the method of algebraic addition of forces is determined for the most loaded sliding surface by the formula [20]: 


$$
n=\frac{\sum_{i}\left[\left(N_{i}-D_{i}\right) \operatorname{tg} \varphi_{i}+C_{i} l_{i}\right]}{\sum_{i} T_{i}},
$$

where $N_{i}$ - is the normal weight component of a single layer, $\mathrm{t} ; D_{i}$ - hydrostatic pressure force, $\mathrm{t} ; \varphi-$ angle of internal friction of the rock, deg; $C$ - adhesion of the rock, $\mathrm{kg} / \mathrm{cm}^{2} ; l_{i}$ - is the length of the segments of the probable sliding surface (the length of the base of the layer), m; $T_{i}-$ is the tangent component of the weight of a single tier, $t$.

Given the above simulation results, it is proved that the joint storage of overburden and dehydrated waste by the method of funnel formation is possible in the dumps of the Horishno-Plavnivske deposit.

\section{CONCLUSIONS and prospects for further research.}

As a result of the geomechanical modeling for the formation of a compatible dump of waste rock and dehydrated waste in the funnels, the predicted behavior of the dump during the entire period of its operation is established. The values of the maximum deformations of the dump in the process of its formation in layers are obtained and a constant increase of deformation during the formation of each subsequent layer is established. However, there is no clear pattern between the increase in deformations of adjacent layers.

The value of the coefficient of stability of the joint dump after its formation was determined and it was found that its value exceeds the minimum allowable, according to current regulations $(n=1,329>1,3)$, that is, the formation of the dump and its further operation with joint placement of rocks and waste enrichment is possible and appropriate.

The obtained research results proved the prospects of scientific and research work in this direction, as the problem of dumping of enrichment waste is very acute. Further research will be aimed at determining the optimal parameters of joint dumping for the maximum possible placement of tails, the behavior of dumps in difficult meteorological and climatic conditions and forecasting their stability.

\section{REFERENCES}

[1] M. Dash, R.K. Dwari, S.K. Biswal, «Studies on the effect of flocculant adsorption on the dewatering of iron ore tailings», Chemacal Engineering Journal, vol. 173, pp. 318-325, 2011.

[2] T. Meggyes, «Paste and Thickened Tailings Technology», Federal Institute for Materials Research and Testing (BAM Forshungsbericht 280), no. 11, 21-39, 2007.

[3] A. Alamgir, D. Harbottle, J. Masliyah, «AL PAM assisted filtration system for abatement of mature fine tailings», Chemical Engineering Science, vol.80, pp.91-99, 2012

[4] O.A. Medvedjeva, S.M.Kyrychko, «Obg'runtuvannja tehnologij spil'nogo skladuvannja vidhodiv zbagachennja z riznymy stepenjamy zgushhennja», Geomehanichna mehanika, vyp. 109, pp. 134$141,2013$.

[5] 7. A.A. Shershnev, S.P. Bakhaeva, "Technological schemes for the storage of tailings in prepared overburden dumps", Vesnik Kuzbaskogo GTU, no. 3, pp. 46-49, 2020.

[6] Yu. S. Gaponov, "Geomechanical substantiation of the stability of rock dumps taking into account the influence of the characteristics of destroyed rock mass", dis. cand. tech. Sci., St. Petersburg Mining University, St. Petersburg, 2015.

[7] A.D. Vasil'eva, "Engineering-geological substantiation of the stability of high dumps of coal deposits of Kuzbass", dis. candidate of Engineering Sci., St. Petersburg Mining University, St. Petersburg, 2020.

[8] A.A. Agafonov, T.V. Porshneva, «Substation of stable parameters of dumps based on a geomechanical model of the designet objects», Mining information and analytical bulletin, no.31 , pp. 5-20, 2020.

[9] C. Francesca, L. Stefano, «Study of large deformation geomechanical problems with the material; point method», Prof. University of Padua, Italy, 2015.

[10] E. Alonso, N. Pinyol, and A. Yerro. «Mathematical Modelling of Slopes», In Procedia Earth and Planetary Science, Volume 9, pp. 64-73, 2014. 
[11] M. Abdula, M. Sharifzadeh, «Probability Methods for Stability Design of Open Pit Rock Slopes: An Overview», Geosciences, no.11, p. 319, 2021.

[12] H. Basahel, H. Mitri, «Probabilistic assessment of rock slopes stability using the response surface approach», International Journal of Mining Science and Technology Volume 29, Issue 3, pp. 357-370, 2019.

[13] V.F. Baranov, "Systems for thickening and storage of tailings dump (review of world practice", Ore dressing, vol. 3, pp. 43-48, 2009.

[14] S.V. Tsirel, Yu.S. Gaponov, A.A. Pavlovich, "Granulometric composition, shear strength of destroyed rocks, and their influence on the stability of dumps", Mining information and analytical bulletin, no. 12, pp. 80-83, 2013.

[15] O.O. Frolov, I.K. Babychev, I.B. Stetskiv, OM Klevan, «Modeling of elastic-plastic deformation of pit edge during pit wall coal margin excavation», The Journal of Zhytomyr State Technological University”, №3(74), pp. 148-155, 2015.

[16] O.O. Frolov, I.K. Babychev, «Vstanovlennja deformacii' bortiv rozrizu pislja vidrobky prybortovyh zapasiv vugillja», Visnyk NTUU «KPI». Serija «Girnyctvo», vyp.31, s.48-56, 2016.

[17] I.K. Babychev, «Naukovo-doslidna robota «Sumisne skladuvannja rozkryvnyh porid $\mathrm{z}$ kar'jeru ta osushenyh vidhodiv vid zbagachennja u vidvalah PRAT «Poltavs'kyj GZK»., Kyi'v: TOV «DJuIS», dogovir №79 vid 19.01.21, 79 s., 2021.

[18] A.A. Frolov, I.K. Babychev, «Justification of the safe parameters of the dump with simultaneous dumping of overburden rocks and processing waste», The Journal "Technical Engineering", №1(87), pp.163-168, 2021.

[19] Ministerstvo promislovoï politiki Ukraïni, Normi tehnologichnogo proektuvannja girnichodobuvnih pidpriemstv vidkritim sposobom rozrobki rodovishh korisnih kopalin. Ch. 1 ta 2. Girnichi roboti. Likvidacija girnichodobuvnih pidpriemstv. Tehniko-ekonomichna ocinka ta pokazniki. SOU-MPP 73.020-078-1:2007, Kï̈v, 2007.

[20] Metodicheskie ukazanija po raschetu ustojchivosti i nesushhej sposobnosti otvalov, VNIMI, 127 s., 1987.

К. Бабичев *, аспірант, ORCID: 0000-0002-5771-1087

І.М. Свтушенко, студ., О.О. Фролов, д.т.н., проф., ORCID: 0000-0001-8053-2653 КПІ ім. Ігоря Сікорського, Київ, Україна

* Вiдповідальний автор: i.babichev@ukr.net Стаття подана 21.09.2021; Стаття прийнята 30.09.2021

\section{МОДЕЛЮВАННЯ ФОРМУВАННЯ ВІДВАЛУ РОЗКРИВНИХ ПОРІД КАР'ЄРУ 3 РОЗМІЩЕННЯМ В НЬОМУ ВІДХОДІВ ЗБАГАЧЕННЯ ЗАЛІЗНОЇ РУДИ}

Мета. Метою досліджень, представлених в статті, є обгрунтування можливості формування відвалу при сумісному складуванні розкривних порід кар'єру та відходів збагачення залізної руди при розробці Горішньо-Плавнівського родовища залізистих кварцитів.

Завдання. Виконати геомеханічне моделювання поведінки відвалу розкривних порід кар'єру 3 розміщенням у ньому воронок з відходами збагачення та встановити можливість їхнього сумісного складування в умовах відвалів Горішньо-Плавнівського родовища; встановити закономірності розвитку деформаційних процесів у відвалі по мірі будівництва кожного ярусу при складуванні відходів збагачення у воронки та розрахувати коефіцієнт запасу стійкості відвалу після його формування.

Методи дослідження. Для досягнення поставленої мети досліджень використано: метод комплексного аналізу - для узагальнення попередніх наукових досліджень щодо встановлення та обгрунтування найбільш раціонального способу складування відходів збагачення; методи моделювання - для встановлення можливості та доцільності сумісного складування продуктів збагачення та гірських порід розкриву з кар'єра.

Наукова новизна. Для умов Горішньо-Плавнівського родовища залізистих кварцитів методом геомеханічного моделювання обгрунтована доцільність і можливість розміщення зневоднених відходів збагачення у воронках на відвалах розкривних гірських порід. 
Висновки та практичне значення статті. За результатами досліджень отримана прогнозна поведінка сумісного відвалу протягом всього терміну його експлуатації. Отримані значення максимальних деформацій відвалу в процесі його формування по ярусам та встановлена послідовність підвищення деформації при формуванні кожного наступного ярусу. Розрахований показник коефіцієнту запасу стійкості сумісного відвалу після його формування та встановлено, що його значення перевищує мінімальне припустиме, згідно діючих норм $(\mathrm{n}=1,329>1,3)$, тобто формування відвалу та його подальша експлуатація з сумісним розміщенням в ньому гірських порід розкриву та відходів збагачення є можливим і доцільним.

Ключові слова: кар'єр, відходи, залізна руда, родовище, геомеханічне моделювання, деформація, коефіuієен запасів

\section{СПИСОК ВИКОРИСТАНОЇ ЛИТЕРАТУРИ}

[1] M. Dash, R.K. Dwari, S.K. Biswal, «Studies on the effect of flocculant adsorption on the dewatering of iron ore tailings», Chemacal Engineering Journal, vol. 173, pp. 318-325, 2011.

[2] T. Meggyes, «Paste and Thickened Tailings Technology», Federal Institute for Materials Research and Testing (BAM Forshungsbericht 280), no. 11, 21-39, 2007.

[3] A. Alamgir, D. Harbottle, J. Masliyah, «AL PAM assisted filtration system for abatement of mature fine tailings», Chemical Engineering Science, vol.80, pp.91-99, 2012

[4] O.A. Medvedjeva, S.M.Kyrychko, «Obg'runtuvannja tehnologij spil'nogo skladuvannja vidhodiv zbagachennja z riznymy stepenjamy zgushhennja», Geomehanichna mehanika, 109, pp. 134-141, 2013.

[5] A.A. Shershnev, S.P. Bakhaeva, "Technological schemes for the storage of tailings in prepared overburden dumps", Vesnik Kuzbaskogo GTU, no. 3, pp. 46-49, 2020.

[6] Yu. S. Gaponov, "Geomechanical substantiation of the stability of rock dumps taking into account the influence of the characteristics of destroyed rock mass", dis. cand. tech. Sci., St. Petersburg Mining University, St. Petersburg, 2015.

[7] A.D. Vasil'eva, "Engineering-geological substantiation of the stability of high dumps of coal deposits of Kuzbass", dis. candidate of Engineering Sci., St. Petersburg Mining University, St. Petersburg, 2020.

[8] A.A. Agafonov, T.V. Porshneva, «Substation of stable parameters of dumps based on a geomechanical model of the designet objects», Mining information and analytical bulletin, no.3-1, pp. 5-20, 2020.

[9] C. Francesca, L. Stefano, «Study of large deformation geomechanical problems with the material; point method», Prof. University of Padua, Italy, 2015.

[10] E. Alonso, N. Pinyol, and A. Yerro. «Mathematical Modelling of Slopes», In Procedia Earth and Planetary Science, Volume 9, pp. 64-73, 2014.

[11] M. Abdula, M. Sharifzadeh, «Probability Methods for Stability Design of Open Pit Rock Slopes: An Overview», Geosciences, no.11, p. 319, 2021.

[12] H. Basahel, H. Mitri, «Probabilistic assessment of rock slopes stability using the response surface approach», International Journal of Mining Science and Technology Volume 29, Issue 3, pp. 357-370, 2019.

[13] V.F. Baranov, "Systems for thickening and storage of tailings dump (review of world practice", Ore dressing, vol. 3, pp. 43-48, 2009.

[14] S.V. Tsirel, Yu.S. Gaponov, A.A. Pavlovich, "Granulometric composition, shear strength of destroyed rocks, and their influence on the stability of dumps", Mining information and analytical bulletin, no. 12, pp. 80-83, 2013.

[15] O.O. Frolov, I.K. Babychev, I.B. Stetskiv, OM Klevan, «Modeling of elastic-plastic deformation of pit edge during pit wall coal margin excavation», The Journal of Zhytomyr State Technological University", №3(74), pp. 148-155, 2015.

[16] O.O. Frolov, I.K. Babychev, «Vstanovlennja deformacii' bortiv rozrizu pislja vidrobky prybortovyh zapasiv vugillja», Visnyk NTUU «KPI». Serija «Girnyctvo», vyp.31, s.48-56, 2016.

[17] I.K. Babychev, «Naukovo-doslidna robota «Sumisne skladuvannja rozkryvnyh porid z kar'jeru ta osushenyh vidhodiv vid zbagachennja u vidvalah PRAT «Poltavs'kyj GZK»., Kyi'v: TOV «DJuIS», dogovir №79 vid 19.01.21, 79 s., 2021.

[18] A.A. Frolov, I.K. Babychev, «Justification of the safe parameters of the dump with simultaneous dumping of overburden rocks and processing waste», The Journal "Technical Engineering", №1(87), pp.163-168, 2021.

[19] Ministerstvo promislovoï politiki Ukraïni, Normi tehnologichnogo proektuvannja girnichodobuvnih pidpriemstv vidkritim sposobom rozrobki rodovishh korisnih kopalin. Ch. 1 ta 2. Girnichi roboti. Likvidacija girnichodobuvnih pidpriemstv. Tehniko-ekonomichna ocinka ta pokazniki. SOU-MPP 73.020-078-1:2007, Kiïv, 2007.

[20] Metodicheskie ukazanija po raschetu ustojchivosti i nesushhej sposobnosti otvalov, VNIMI, 127 s., 1987. 